\title{
The C4 Model of People-Centered Innovation: Culture, Consciousness, and Customer-Centric Co-Creation
}

\author{
Rick L. Edgeman and Jacob Kjær Eskildsen
}

ICOA, Aarhus University, Aarhus, Denmark

\begin{abstract}
Quality in its contemporary incarnation is commonly referred to as organizational excellence, enterprise excellence, business excellence, or performance excellence. While technology may serve as a key enabler of enterprise excellence, enterprise excellence itself is in large enabled by the human dimension both in terms of ideation and effort. The human dimension manifests in many ways, with people-centered innovation representing a critical intersection of the market environment and the enterprise's human capital or the individual inventor.

Innovation in all its faces and forms can be more effectively and strategically attained through collaboration that extends throughout the enterprise, to its supply chain, and ultimately to the marketplace itself, that is, cooperation between the enterprise and the culture(s) it serves via the process of co-creation.

Understanding of, sensitivity to, and leverage of culture as broadly construed is an underdeveloped aspect enterprise excellence. As considered herein, innovation contributes to enterprise excellence through conscious and customer-centric collaboration between the enterprise and the culture. As such we explore intersections among cultural anthropology, innovation, and enterprise excellence by more thoughtfully elaborating the interface between the enterprise and the customer (user) culture, including society.
\end{abstract}

Keywords: Collaboration; Co-Creation; Consciousness; Intentionality.

\section{Introduction}

Culture is considered herein as a transmission medium by which peopledriven innovation occurs. There is little doubt that cultures and organizations interact and that interaction is a necessity, but not sufficient condition to the prosperity - if not survival - of most organizations. Critical is the nature of such interaction: intentional or passive, mutually enriching, or antagonistic.
We regard self-evident that interaction best enabling people-driven innovation is active, mutually enriching, and promotes a customer-centric approach that is both conscious and collaborative where, by conscious, it is meant that it is intentional. A uni-cultural expression of this occurs when an organization is embedded in a single culture, and where enrichment of the culture, to the mutual benefit of the organization and

Copyright (C) 2012 Rick L. Edgeman and Jacob Kjær Eskildsen. This is an open access article distributed under the Creative Commons Attribution License unported 3.0, which permits unrestricted use, distribution, and reproduction in any medium, provided that original work is properly cited. Contact author: Rick L. Edgeman Email: rledge@asb.dk 
the culture alike, comes about through understanding, appreciating, and collaborating with the culture. Depending on its scope, mission, and vision an organization may exist either wholly within a single culture or, as is increasingly common in the global marketplace will cross and interact with many cultures while also possessing a culture of its own.

It is not here implied that of necessity an organization must comprehensively understand the culture in which it functions, but rather that appropriate contextualization of such understanding in ways aligning with the organization's own mission, vision and culture will benefit the organization and culture alike. This suggests that failed or suboptimal innovation - not necessarily "no" innovation, but innovation with the wrong trajectory - may be consequential to improper consideration of the cultural dimension. Terwiesch and Ulrich (2009) argue that while innovation is seen as a largely creative endeavor, it can also be rigorously managed by viewing and structuring the innovation process as a collection of "opportunities" and then identifying the most exceptional among these. Complementary to Terwiesch and Ulrich it is here promoted that "exceptional opportunities" are more surely birthed by culturally-informed collaboration.

Often collaboration entails essentially invisible structures where knowledge grows exuberantly and proliferates in unforeseeable ways. Core to more extensive and more rapid proliferation is reliance on conscious collaboration among individuals, units, and organizations where numerous tools and techniques capable of adding structure to such collaboration are available. The System of Profound Consciousness (SYPROCON) developed by Edgeman and Fraley (2008) and employed herein demands such collaboration and is itself reliant on Husserl's doctrine of intentionality (Welton, 1999) which states that consciousness - our direct openness to the world - is always intentional.

\section{Profound Consciousness}

The idea behind profound consciousness is that "people create barriers between each other by their fragmentary thought with each one operating separately." This idea was promoted by noted physicist, Sir David Bohm, as he noted that when these barriers have dissolved, then "there arises one mind, where they are all one unit, but each person also retains his or her own individual awareness" (Jaworski, 1996: 80-81).

Devoid of consciousness, a system cannot understand itself, hence the need for a more transcendent range of knowledge and experience that only an external influence or agent can infuse. This generates a more extensive collective knowledge base that, with understanding of interrelationships and adaptation of these to us, contributes not only to increased collective consciousness, but to more productive collaboration. Models developed by Edgeman and Fraley (2008) in support of SYPROCON posit that profoundly knowledgeable or conscious individuals inspire others in the enterprise - that consciousness is contagious - and that once a critical and strategic mass of such individuals exists that profoundly conscious teams form and operate, initiating the emergence of a profoundly conscious enterprise.

Such enterprises are highly collaborative, leading to reduction or elimination of both local and global sub-optimalities as - in some sense - more synapses are formed in the enterprise mind, thus enabling the organization's human capital to better understand its systems and one another and hence to function more efficiently, effectively, and insightfully both individually and collaboratively; in order to develop new processes, products, and solutions to problems that benefit all enterprise stakeholders while avoiding tangible harm to those who either do not have voice or do not have clear stake in the activities or results of the enterprise. 
At the enterprise level, profound consciousness integrates soft technologies of the mind with harder, more scientificallyoriented technologies to function as a sort of Hive Mind (Hegel, 1807), that is, a nonlocal and atemporal awareness of all aggregates, components, constituents, entities, personalities, relationships, technologies, processes and cycles of the enterprise. Critical to this work is the word "constituent" as the intent herein is to involve "cultures" and their people as co-creators, co-innovators.

As enterprises interact with one another, consciousness proliferates both in terms of breadth and richness. Societies - cultures are in many ways collections of organizations with our world being a collection of societies, and hence as it proliferates, profound consciousness may be regarded as an extension of the vision of noted evolutionary biologist, Marcos B. Viermenhouk (Williams, 2009) to a transformed and profoundly knowledgeable and conscious world as a sort of conscious macro-organism.

In elaborating SYPROCON, Edgeman and Fraley built on and integrated aspects of the works of Max-Neef and Reiss. Max-Neef (1991) argued that needs are simultaneous and complementary with their satisfaction based on trade-offs whereas Reiss developed a model based on 16 needs or desires, henceforth called dimensions of motivation (Reiss 2000, 2008) that, he argued, are ontologically universal and invariant - part of the human condition - for each of which he asserts distinct genetic origins with invariance implying constancy across all human cultures and time periods where what changes between cultures and over time is how these dimensions are satisfied and balanced. Edgeman and Fraley adapted a subset of ten of Reiss' dimensions for both individual and organizational manifestation and, in the manner of Max-Neef, overlaid these with the classical existentialist categories of authenticity of being, corporeal and mental action (doing), having (things), and communication and interaction. Linked to authenticity of being is intentionality. Intentionality is cornerstone to models developed by Edgeman and Fraley for the "individual in the organization" and "teams or organizations comprised of such individuals".

These models are referred to as CIMIO (Conscious Intention Model of the Individual in the Organization) and COM (Conscious Organization Model). After modification to reflect people-centered innovation, these are referred to as PCI-CIMIO and PCI-COM, respectively. 
Table 1. Integration of People-Centered Innovation Integration and CIMIO

\begin{tabular}{|c|c|c|c|c|}
\hline Dimension & \multicolumn{4}{|c|}{ Existential Categories } \\
\hline $\begin{array}{l}\text { Dimension } \\
\text { Name }\end{array}$ & $\begin{array}{l}\text { Authenticity of } \\
\text { Being }\end{array}$ & Having (Things) & $\begin{array}{l}\text { Corporeal and } \\
\text { Mental Action }\end{array}$ & $\begin{array}{l}\text { Communication } \\
\text { \& Interaction }\end{array}$ \\
\hline Acceptance & $\begin{array}{l}\text { effective, well- } \\
\text { liked, accepting } \\
\text { of chaos }\end{array}$ & $\begin{array}{l}\text { sensing skills, } \\
\text { emotional } \\
\text { flexibility }\end{array}$ & $\begin{array}{l}\text { engagement, } \\
\text { dialogue, } \\
\text { leadership }\end{array}$ & $\begin{array}{l}\text { teams, training, } \\
\text { ideation } \\
\text { activities }\end{array}$ \\
\hline Curiosity & $\begin{array}{l}\text { inquisitive, active } \\
\text { learner }\end{array}$ & $\begin{array}{l}\text { creative freedom, } \\
\text { learn from others }\end{array}$ & $\begin{array}{l}\text { research, } \\
\text { problem-solving, } \\
\text { inquiry }\end{array}$ & $\begin{array}{l}\text { teams, discovery } \\
\text { activities, }\end{array}$ \\
\hline Idealism & $\begin{array}{l}\text { passionate, } \\
\text { optimistic, } \\
\text { outreach- } \\
\text { oriented }\end{array}$ & $\begin{array}{l}\text { energy, impetus, } \\
\text { confidence }\end{array}$ & $\begin{array}{l}\text { vision, goal } \\
\text { setting, idea } \\
\text { sharing }\end{array}$ & $\begin{array}{l}\text { teams, external } \\
\text { involvement, } \\
\text { social settings }\end{array}$ \\
\hline Independence & $\begin{array}{l}\text { autonomy, open- } \\
\text { mindedness, self- } \\
\text { confident, } \\
\text { passion }\end{array}$ & $\begin{array}{l}\text { equal rights, high } \\
\text { contribution level, } \\
\text { freedom of } \\
\text { expression }\end{array}$ & $\begin{array}{l}\text { taking initiative, } \\
\text { dissent, choosing, } \\
\text { run risks, } \\
\text { contribution }\end{array}$ & anywhere \\
\hline Order & $\begin{array}{l}\text { intrinsic } \\
\text { structure, } \\
\text { process \& system } \\
\text { orientation }\end{array}$ & $\begin{array}{l}\text { sense of control } \\
\text { over environment } \\
\text { and self }\end{array}$ & $\begin{array}{l}\text { leadership, goal } \\
\text { setting, planning, } \\
\text { facilitation }\end{array}$ & $\begin{array}{l}\text { administration, } \\
\text { work, teams }\end{array}$ \\
\hline Power & $\begin{array}{l}\text { keen awareness } \\
\text { of needs of self } \\
\text { and others, } \\
\text { confidence }\end{array}$ & $\begin{array}{l}\text { effectiveness, } \\
\text { competence, } \\
\text { passion, decision- } \\
\text { making authority }\end{array}$ & $\begin{array}{l}\text { leadership, risk } \\
\text { taking, } \\
\text { constructive } \\
\text { conflict, } \\
\text { collaboration }\end{array}$ & $\begin{array}{l}\text { administration, } \\
\text { work teams, } \\
\text { appropriate } \\
\text { enterprise-level } \\
\text { reports }\end{array}$ \\
\hline Saving & $\begin{array}{l}\text { conscientious, } \\
\text { conscious, now \& } \\
\text { next orientation }\end{array}$ & $\begin{array}{l}\text { strategic resource } \\
\text { conservation, } \\
\text { sense of } \\
\text { stewardship }\end{array}$ & $\begin{array}{l}\text { sustainability } \\
\text { aware and active, } \\
\text { lean approaches }\end{array}$ & $\begin{array}{l}\text { administration, } \\
\text { partnerships, } \\
\text { strategic } \\
\text { alliances }\end{array}$ \\
\hline Social Contact & $\begin{array}{l}\text { synergy, } \\
\text { connectedness, } \\
\text { external } \\
\text { involvement }\end{array}$ & $\begin{array}{l}\text { networks, teams, } \\
\text { external } \\
\text { engagements }\end{array}$ & $\begin{array}{l}\text { collaboration, } \\
\text { alliance building, } \\
\text { facilitation, } \\
\text { negotiation }\end{array}$ & $\begin{array}{l}\text { one-on-one, } \\
\text { teams or groups, } \\
\text { customers, other } \\
\text { stakeholders }\end{array}$ \\
\hline Status & $\begin{array}{l}\text { awareness of } \\
\text { potential to learn } \\
\text { and contribute }\end{array}$ & $\begin{array}{l}\text { acknowledged as } \\
\text { a thought leader, } \\
\text { well-connected }\end{array}$ & $\begin{array}{l}\text { creative, } \\
\text { collaborative, and } \\
\text { innovative }\end{array}$ & $\begin{array}{l}\text { Team and group } \\
\text { meetings, } \\
\text { electronic or } \\
\text { written memos }\end{array}$ \\
\hline $\begin{array}{l}\text { Forgiveness as } \\
\text { anti- } \\
\text { vengeance }\end{array}$ & $\begin{array}{l}\text { teachable, } \\
\text { facilitative, } \\
\text { accountable, } \\
\text { tolerant of some } \\
\text { level of chaos }\end{array}$ & $\begin{array}{l}\text { sense of } \\
\text { empowerment, } \\
\text { accountability, } \\
\text { appreciation of } \\
\text { ideas of others }\end{array}$ & $\begin{array}{l}\text { admit and learn } \\
\text { from mistakes and } \\
\text { from others, move } \\
\text { forward, making } \\
\text { amends, } \\
\text { thoughtful risk- } \\
\text { taking, }\end{array}$ & $\begin{array}{l}\text { team } \\
\text { environments, } \\
\text { with peers, } \\
\text { within } \\
\text { organizational } \\
\text { chain of } \\
\text { command }\end{array}$ \\
\hline & & & & \\
\hline
\end{tabular}


Table 2: Integration of People-Centered Innovation and COM

\begin{tabular}{|c|c|c|c|c|}
\hline Dimension & \multicolumn{4}{|c|}{ Existential Categories } \\
\hline Dimension Name & Authenticity of Being & | Having (Things) & $\begin{array}{l}\text { Corporeal and Mental } \\
\text { Action }\end{array}$ & $\begin{array}{l}\text { Communication \& } \\
\text { Interaction }\end{array}$ \\
\hline Acceptance & $\begin{array}{l}\text { effective, engaged in } \\
\text { and respected by the } \\
\text { community }\end{array}$ & $\begin{array}{l}\text { market penetration, } \\
\text { cultural anticipation of } \\
\text { new products \& } \\
\text { services }\end{array}$ & $\begin{array}{l}\text { collaboration, } \\
\text { suggestions, active } \\
\text { engagement of } \\
\text { stakeholders }\end{array}$ & $\begin{array}{l}\text { teams, meetings, } \\
\text { conferences, public } \\
\text { forums and reports }\end{array}$ \\
\hline Curiosity & $\begin{array}{l}\text { exploratory, creative, } \\
\text { inventive, } \\
\text { innovative }\end{array}$ & $\begin{array}{l}\text { strong culture of } \\
\text { collaboration, fast- } \\
\text { learning orientation }\end{array}$ & $\begin{array}{l}\text { focus groups, active } \\
\text { inquiry, organize to } \\
\text { learn from others }\end{array}$ & $\begin{array}{l}\text { brainstorming } \\
\text { sessions, focus } \\
\text { groups, public } \\
\text { engagement }\end{array}$ \\
\hline Idealism & $\begin{array}{l}\text { strong CSER and } \\
\text { "can-do" mindsets }\end{array}$ & self-respect, authority & $\begin{array}{l}\text { visionary, goal setting, } \\
\text { creative problem- } \\
\text { solving }\end{array}$ & $\begin{array}{l}\text { focus groups, public } \\
\text { involvement }\end{array}$ \\
\hline Independence & $\begin{array}{l}\text { open-mindedness, } \\
\text { passion for co- } \\
\text { creation }\end{array}$ & $\begin{array}{l}\text { empowerment, equal } \\
\text { rights, rich and diverse } \\
\text { ideas }\end{array}$ & $\begin{array}{l}\text { dissent, choosing, } \\
\text { creative conflict, } \\
\text { develop awareness } \\
\end{array}$ & $\begin{array}{l}\text { brainstorming, } \\
\text { stakeholder } \\
\text { engagement }\end{array}$ \\
\hline Order & $\begin{array}{l}\text { value structured } \\
\text { engaged learning } \\
\text { from and with } \\
\text { stakeholders, highly } \\
\text { purposeful } \\
\text { engagement }\end{array}$ & $\begin{array}{l}\text { common enterprise } \\
\text { vocabulary, shared } \\
\text { culture vocabulary, } \\
\text { change management } \\
\text { competence }\end{array}$ & $\begin{array}{l}\text { structured problem- } \\
\text { solving, project } \\
\text { management, highly } \\
\text { structured innovation } \\
\text { and co-creation } \\
\text { processes }\end{array}$ & $\begin{array}{l}\text { in teams, e-mail, } \\
\text { conference calls, } \\
\text { presentations, } \\
\text { conferences, public } \\
\text { forums, focus groups }\end{array}$ \\
\hline Power & $\begin{array}{l}\text { public influence, } \\
\text { strong internal } \\
\text { shared sense of } \\
\text { purpose }\end{array}$ & $\begin{array}{l}\text { market share, decision- } \\
\text { making authority, } \\
\text { training, resources, } \\
\text { public awareness of } \\
\text { and respect }\end{array}$ & $\begin{array}{l}\text { strategic planning, } \\
\text { sharing of power, } \\
\text { awareness campaigns, } \\
\text { publicly impactful } \\
\text { innovation }\end{array}$ & $\begin{array}{l}\text { market place, impact, } \\
\text { across supply chain, } \\
\text { public forums \& } \\
\text { events, publicly } \\
\text { available reports. }\end{array}$ \\
\hline Saving & $\begin{array}{l}\text { specific, relevant, } \\
\text { value-oriented, } \\
\text { responsible }\end{array}$ & $\begin{array}{l}\text { measurable and } \\
\text { attainable goals, highly } \\
\text { relevant CSER goals }\end{array}$ & $\begin{array}{l}\text { lean approaches, } \\
\text { responsible designs, } \\
\text { socially relevant } \\
\text { innovation }\end{array}$ & $\begin{array}{l}\text { financial planning } \\
\text { sessions, goal setting, } \\
\text { relevant publicly } \\
\text { available reports }\end{array}$ \\
\hline Social Contact & $\begin{array}{l}\text { connected, non- } \\
\text { judgmental, } \\
\text { cooperative, } \\
\text { collaborative, social } \\
\text { value }\end{array}$ & $\begin{array}{l}\text { respect for and from of } \\
\text { others, influence in } \\
\text { relevant communities }\end{array}$ & $\begin{array}{l}\text { Conduct focus groups, } \\
\text { participate in public } \\
\text { dialogues, issue } \\
\text { relevant reports }\end{array}$ & $\begin{array}{l}\text { training sessions, } \\
\text { team meetings, } \\
\text { retreats, suppliers/ } \\
\text { customers, focus } \\
\text { groups }\end{array}$ \\
\hline Status & $\begin{array}{l}\text { respected by others, } \\
\text { humility, publicly and } \\
\text { privately influential }\end{array}$ & $\begin{array}{l}\text { strong excellence and } \\
\text { CSER reputation, } \\
\text { tangible rewards, } \\
\text { market share }\end{array}$ & $\begin{array}{l}\text { organize future } \\
\text { growth, motivate self } \\
\text { and others to change in } \\
\text { relevant and } \\
\text { responsible ways }\end{array}$ & $\begin{array}{l}\text { various media, } \\
\text { industry and public } \\
\text { events, across supply } \\
\text { chain, influence in } \\
\text { external } \\
\text { organizations }\end{array}$ \\
\hline $\begin{array}{l}\text { Forgiveness as } \\
\text { anti-vengeance }\end{array}$ & $\begin{array}{l}\text { learning organization, } \\
\text { trust, confident, } \\
\text { courage, humble, } \\
\text { accountable }\end{array}$ & \begin{tabular}{|l|} 
culture valuing \\
empowerment, \\
accountability, sense of \\
appreciation, open \\
dialogue
\end{tabular} & $\begin{array}{l}\text { transparency, reward } \\
\text { and recognition system } \\
\text { encourages openness } \\
\text { and risk-taking }\end{array}$ & $\begin{array}{l}\text { across entire } \\
\text { enterprise chain of } \\
\text { command, public } \\
\text { availability and } \\
\text { accountability }\end{array}$ \\
\hline
\end{tabular}


The goal of extending SYPROCON from the individual expression of PCI-CIMIO (Table 1) to a collective expression led to development of PCI-COM (Table 2), with the journey to becoming a profoundly conscious organization facilitated by collaboration among profoundly conscious individuals and the culture.

Porter (1985) introduced value chains with extension to a larger value system. The point of a value chain is synergy - that a linked chain of activities adds greater value to a product than the sum of added values of all activities considered individually. Industrywide synchronized interactions of local value chains create a value system of possible global extent. A value system includes the value chains of an organization's suppliers, and in turn their suppliers, ad infinitum, the organization itself, organizational distribution channels, and the organization's customers - presumably extended to their customers. These ideas were extended to supply chains integrating key business processes from end user to original suppliers with attention increasingly focused on the social dimensions of these in competitive contexts and their relationship to corporate social responsibility (Porter and Kramer, 2006). Integration of what may be referred to as profound kyosei yields a subsequent extension to a profoundly conscious supply chain, where kyosei is a Japanese term meaning "living and working together for the common good" or what might be refered to as mutual engagement and enrichment. Such systems and chains are often intercultural and the system must be symbiotic to the culture(s) so that profound consciousness is organic to mutual enrichment in all cases involving collaboration of two or more individuals or entities.

\section{Customer-Centric Co-Creation: The Culture-Organization Interface}

Profoundly conscious organizations will be cognizant of value chains, value systems, supply chains, and social responsibility with customers and culture integral to each of these chains so that customer and cultural needs are of organizational import. One wellknown customer needs model is that of Kano (Kano, et. al., 1984). Such models employ dissatisfiers, satisfiers, and delighters where dissatisfiers are "must haves" that are absolutely expected, satisfiers are onedimensional aspects such as fuel efficiency (more is better), and delighters are "attractive" or positively "surprising" aspects of quality. Generally, a product or service should possess all must haves, maximize onedimensional needs, and include some delighters.

A satisfier of one need may inhibit the ability to satisfy one or more other needs - a concept addressed by the roof of the socalled "house of quality" that is foundational to quality function deployment (QFD), where measurable means of fulfilling customer needs ("how's"), needs, and their correlations are represented, indicating that how's can oppose, be independent of, or synergistic with one another in their abilities to satisfy the so-called what's that represent the voice of the customer (VOC) - that is - specifically elicited and carefully elaborated customer needs.

Product or service specificity enables citation of features and aspects corresponding to Garvin's (1987) eight dimensions of quality satisfying various customer wants or needs. Neither Kano's customer needs nor Garvin's dimensions of quality should be confused with the basic human needs or desires identified in the CIMIO and COM models, though correlations would in many instances be expected, so that customer needs or wants and basic human needs, while not identical, often intertwine and may be difficult to distinguish. As such it is important to actively listen to and engage those for and with whom we are innovating as we ascertain and elaborate these needs. In referring to this cocreation process Anna Kirah asserted that:

"Change does not happen until different areas within the same companies learn to speak the same language as the culture of the people 
they are innovating for and that they can speak together across disciplines" (Jokisalo, 2008:1).

Kirah, a cultural anthropologist, notes that human aspirations and motivations lead people to act and to become lifelong learners in a society. Assessment of such aspirations and motivations often require more than can be gleaned from a customer survey or focus group. Indeed, it requires the practice of kyosei and co-creation. It requires learning as much about the human heart and its desires as it does the human hand and its use of that created. That is:

PEOPLE-CENTERED INNOVATION EQUATION: Kyosei $=$ Collaboration $=$ Co-Innovation $=\mathrm{Co}-$ Creation

We thus infer here that when collaboration is constrained that creativity and hence innovation suffers - whether constraints are formally imposed or whether they arise via oversight, or by lack of vision - what Kirah calls "blinders" (e.g. "we don't know what we don't know"). She went on to express concern that the present educational system too greatly focuses on individual learning - a model that was appropriate during the industrial revolution, but that is now inadequate. Kirah instead asserted that we must be able to work across disciplines and think holistically in order to approach the needed rate of change in our fast-paced global world. This implies need not only for intercultural experience, but also an accompanying mindset.
It is important to integrate satisfaction of customer and cultural needs into enterprise culture and to align these with enterprise purpose so that these permeate individual and organizational consciousness. Among the challenges of successfully achieving integration is attaining congruence of organizational core values, beliefs and attitudes where the issue of competence affecting how thoroughly and effectively values and attitudes drive purpose and deployment. Elements needing alignment include attraction of human capital and along with subsequent and regular enrichment of that capital to fulfill organizational purpose and satisfy customer and cultural needs that is, aspirations and motivations. Enterprise resources are ultimately committed to activities, the intentions of which are to fulfill enterprise purpose with, in turn, enterprise purpose strongly influenced by these aspirations and motivations. The profoundly consciousness organization, then, is aware of these interrelationships and competent enough to align them.

These ideas are captured in the Conscious Alignment and Integration Model (CAIM) of Figure 1, elements of which may vary substantially in size across organizations, with relative size and proximity of elements influenced by organizational competence in specific domains and signaling whether an organization is in decline, at steady state, or becoming profoundly conscious. The model of Figure 1 is produced by modifying one provided by Edgeman and Fraley (2008), with the modification aimed at peoplecentered innovation. 


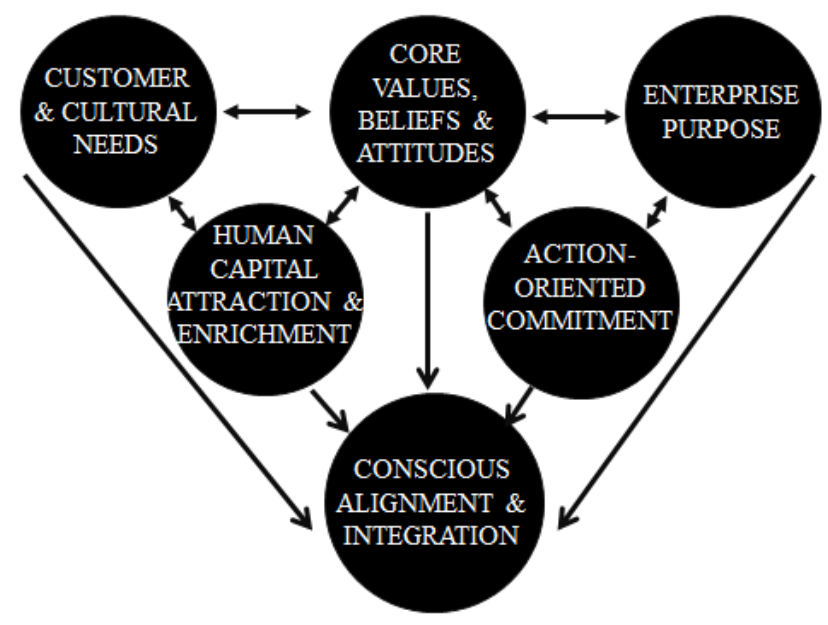

Fig. 1. Conscious Alignment and Integration Model (CAIM) Integrating Customer and Cultural Needs into Enterprise Consciousness.

While CAIM appearance varies across organizations, for the profoundly conscious enterprise, core values and attitudes along with enterprise purpose may remain relatively constant over time with other elements expanding, given growing organizational consciousness and competence so that the relative sizes, proximities, and natures of these circles provide indicators of the extent of integration and "shared consciousness".

Extending collaboration to co-creation through symbiosis of the culture(s) and the organization requires adaptation of the CAIM elements to reflect mutually enriching attunement of the organization to cultural and environmental values and needs.

Consistent with Terwiesch and Ulrich (2009) it should be noted that commonly it is not a single or small innovation that we seek, but rather a combination of many and significant ones. Thus framed it is important to note that the notion of significance is informed by various priorities, for example by some blend of the pillars of the BEST Sustainability / BEST Business Excellence Models of Edgeman (2000, 2001), Edgeman and Hensler (2001, 2005), and Hensler and Edgeman (2002) or by careful consideration of other elements of a socially and environmentally responsible organization.

\section{Co-Creation: Culture and the System of Profound Consciousness}

Convergent integration is the trend toward central convergence that increases organization and growth. Although this runs counter to the sort of entropic forces at work in most unattended processes, it is consistent with collaboration and hence innovation as a result of co-creation. Cooperation and collaboration among a critical mass of individuals, teams and organizations with enhanced consciousness across cultural boundaries produces the mutually enriching results of stimulating growth in collective consciousness with the organization and culture simultaneously becoming increasingly self-actualizing through, in part, increased innovation.

The System of Profound Consciousness, or SYPROCON (Edgeman and Fraley, 2008) as modified to reflect people-centered innovation, is based on the interrelated themes portrayed in Figure 2, with soft boundaries conveying the permeability and mutual interdependence of these themes. In Figure 2 inspiration is regarded as the ability 
to inspire others and may be thought of as a diffusion factor for knowledge and consciousness. Connectivity represents both communication and connectedness within the enterprise, and between the enterprise and culture(s) with which it co-creates and for which it innovates. Metaphorically, connectivity is very much like synapsebridging acetylcholine or connective tissue.

Innovation is fundamentally about learning and co-creation, each of which increases exponentially - that is - become viral (Edgeman and Eskildsen, 2012) - via the cocreation process, thus yielding learning cultures or societies. In turn, co-creation relies on cooperation and collaboration among people, organizations, and cultures as an enriched form of kyosei, where cooperation is the working together of system elements to achieve more omnibus goals in a manner similar to "cooperation" among neurons that creates or contributes to thought and consciousness. As such, the purpose of kyosei is to create and harness synergy "for the common good", a purpose requiring increasingly wise stewardship in each of the sustainability areas of the BEST Model: business, the environment, society, and technology (Edgeman, 2000).

In the prior discussion, stewardship is intended to be understood as the conscious election of service (e.g. "the common good") over self-interest (Block, 1993), so that sustainability is included in the present modified form of SYPROCON. Viewed from the enterprise perspective, much of sustainability is included in the rapidly evolving area of corporate social and environmental responsibility (CSER). While CSER is regarded by many as philanthropy, Kingen and Holmes (2011) stress that CSER provides tangible dividends to the enterprise.

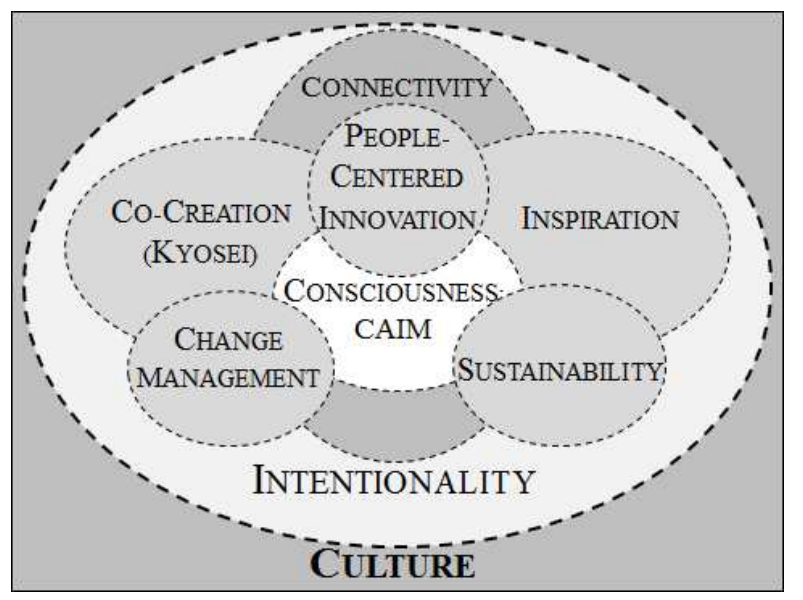

Fig. 2. SYPROCON Adapted to People-Centered Innovation

Identification of CAIM (conscious alignment and integration) as a theme relies strongly on Husserl's doctrine of intentionality and is interwoven with various other themes of both the original and modified forms of SYPROCON. In particular, CAIM and the doctrine of intentionality both inform and influence (people-centered innovation as embodied by learning and co-creation) that which must be aligned, how the alignment is best accomplished strategically (change management) and tactically (kyosei), and toward what ends (sustainability). Successful alignment also requires those driving and implementing change to inspire others, a necessary condition of which is connectivity. As a single example we thus see the inter- 
workings of all the themes of the System of Profound Consciousness.

Inclusion of change management in SYPROCON is motivated by exponential advancement in technology in particular and globally more generally. Change management and people-centered innovation are interdependent in the profoundly conscious organization with what is learned informing what, why and how change occurs, and what is created. That said, according to Kirah (Jokisalo, 2008):

"We are afraid to ask 'Why' and to follow this 'Why' through to making changes to existing products, services and organizations, as well as coming up with innovative solutions that are relevant and meaningful to the very people we are innovating for and with.

When we teach collaborative methods and the art of 'Why' in everything we do, then we allow people to bring meaning into their everyday lives and value comes from meaning."

It is clear from this that the profoundly conscious organization MUST be engaged in the co-creation process with the culture(s) that it serves. As such, and recalling Husserl's assertion that consciousness is always intentional, we regard intentionality as the integrating thread across all themes and cite it as our final SYPROCON theme, without which our "system" is merely a collection of inadequately and sub-optimally assembled components.

\section{People-Centered Innovation at the Nexus of Culture, Collaboration, and Consciousness}

Recall the idea of Sir David Bohm that is behind Profound Consciousness is that "people create barriers between each other by their fragmentary thought. When these barriers have dissolved, then there arises one mind, where they are all one unit, but each person also retains his or her own individual awareness" (Jaworski, 1996: 80-81).
Consistent with this is Senge's (1990) statement that "real learning gets to the heart of what it means to be human. Through learning we re-create ourselves ... become able to do something we never were able to do ... re-perceive the world and our relationship to it ... (and) extend our capacity to create, to be part of the generative process of life. There is within each of us a deep hunger for this type of learning."

Senge subsequently described learning organizations as places "where people continually expand their capacity to create the results they truly desire, where new and expansive patterns of thinking are nurtured, where collective aspiration is set free, and where people are continually learning to see the whole (reality) together."

In a similar vein, Tom Kelley, general manager of America's leading design firm, IDEO, stated that:

"the biggest barrier to innovation, of course, is a company's mind-set ... barriers often stump even the best innovators. They wall in your imagination like a prison yard." (Kelley and Littman, 2001: 165).

From these we see the task before us of identifying and dissolving such barriers on the one hand, and bridging synapses between the enterprise and the culture on the other hand. Kirah refers to these barriers as "blinders" and identifies some of these, while also suggesting an number of means of reducing their negative effects by bridging the synapses (Jokisalo, 2008: 5 and Kirah, 2009). An overview of Kirah's bridges and blinders to innovation can be found in Table 3.

By embracing this anthropologic mindset, we consciously commit to embrace a culture and the minds, hearts, and activities of its people - to serve, subject to reasonable constraints, their aspirations and motivations. In so doing we find the symbiosis of service and self-interest leading to co-creation and - ultimately - not 
simply self-actualization - but rather, mutual actualization.

Numerous methodologies are available to facilitate communication, collaboration, and consensus among and across groups, organizations, or cultures or between an organization and the cultures in which it operates. Generally such methodologies support one or more of three primary objectives that can be described as determining the following (Patrick, 2002):

- What to Change: Situation assessment, description of "current reality," and identification of the core problem or conflict and assumptions that sustain it diagnosis.

- What to Change to: Verbalization of vision/solution and description of strategy to attain the desired state - prescription, decision-making, and solution development.
- How to Make the Change Happen: Development of detailed plans and tactics that will clarify what needs to happen and synchronize the efforts of the group in the implementation of the strategy - planning, team-building.

At variance with Patrick herein is how such methodologies are used since, typically, "customers" - who represent the culture may participate in focus groups or respond to surveys and so on, but are not truly involved in CO-creation. As such, it is here proposed that the above takes place only after the organization and culture - the people - have meaningfully engaged by building and traversing Kirah's bridges to innovation so that the above are practiced as part of the co-creation process. As this process advances then, of course, approaches such as Design for Six Sigma (DFSS) or the Theory of Inventive Problem-Solving (TRIZ) may assist in innovation - but as a conscious consequence of cooperation and collaboration - of co-creation and coinnovation. 
Table 3. Kirah's Barriers and Bridges to Innovation

\begin{tabular}{|c|c|}
\hline Blinders / Barriers to Innovation & $\begin{array}{l}\text { Bridges to Innovation: Means for Removing or } \\
\text { Reducing Negative Effects }\end{array}$ \\
\hline $\begin{array}{l}\text { industrial revolution mindset of individual } \\
\text { learning }\end{array}$ & $\begin{array}{l}\text { People-centric mindset: thinking of the } \\
\text { aspirations and motivations of people in their } \\
\text { everyday and not so everyday lives. Observe } \\
\text { and listen to people doing activities they } \\
\text { define themselves and that are meaningful to } \\
\text { them, as opposed to activities we identify for } \\
\text { them in which to engage. By going beyond our } \\
\text { usual 'users' to "the people" we can learn even } \\
\text { more and this enables us to gain and apply } \\
\text { knowledge to design and develop with people, } \\
\text { rather than simply for people ... this is co- } \\
\text { creation. }\end{array}$ \\
\hline toxic organizational culture & $\begin{array}{l}\text { People-centered concept making with the } \\
\text { goals of optimizing for relevant and } \\
\text { meaningful concept creation and for similarly } \\
\text { relevant and meaningful changes to existing } \\
\text { products and services with people (cultural } \\
\text { engagement). This requires us to go where the } \\
\text { people are and to be willing to listen at their } \\
\text { feet and, also, to create with people in all } \\
\text { stages of development - even before knowing } \\
\text { what is to be created. }\end{array}$ \\
\hline $\begin{array}{l}\text { difficulties adjusting to rapid change in a } \\
\text { global world }\end{array}$ & $\begin{array}{l}\text { Use design anthropology and concept making } \\
\text { to bridge meaning to the design and } \\
\text { development of products and services } \\
\text { throughout the development cycle - } \\
\text { byproducts of which are creation of a people- } \\
\text { centric company culture and strategy and } \\
\text { vision work / modification. }\end{array}$ \\
\hline $\begin{array}{l}\text { the tyranny of the moment: confusing what is } \\
\text { urgent with what is important }\end{array}$ & $\begin{array}{l}\text { Willingness: be willing to step outside your } \\
\text { comfort zone, to build with people as opposed } \\
\text { to simply for them, be willing to be humble } \\
\text { and practice the art of humility by } \\
\text { acknowledging that you may not be the expert } \\
\text { in all regards and that much can be learned } \\
\text { from others, be willing to be flexible and adapt } \\
\text { to any context, and exercise patience by being } \\
\text { willing to live in the question as while } \\
\text { resisting the temptation to leap to a solution. }\end{array}$ \\
\hline $\begin{array}{l}\text { Our mindsets, not our methodologies limit our } \\
\text { innovation. We bring with us our } \\
\text { assumptions. }\end{array}$ & $\begin{array}{l}\text { Challenge all assumptions by adopting the } \\
\text { anthropologic mindset and seeing the world } \\
\text { for what it (really) is. }\end{array}$ \\
\hline
\end{tabular}




\section{Conclusion}

Organizations and society face challenges that are increasing in number, magnitude, and importance. Such challenges include economic, environmental, societal, and technological ones with many of these threatening not only our physical safety and economic security, but also our survival. Given such challenges, conscious alignment of all resources (including human capital) and activities of organizations are not enough.

Organizations have dramatic impacts on society and on the environment so that extending such alignment beyond the organization into society is needed. That said, those communities and individuals not directly on the payroll of an organization must be differently incentivized, with benefits from or due to the organization that are only partially controlled by the organization.

Successfully confronting such challenges requires new kinds of efforts, new kinds of emphases, and new or enhanced ways coordinating and collaborating not only within an organization or spanning its supply chain, but extending to the organizationculture interface. A core purpose of coordination at this interface is that it should result in collaboration and co-creation that lead to improved opportunities and likelihoods of better futures for us all.

Innovation in varied forms for varied purposes is needed and conscious collaboration of this sort results in an innovation process that may be referred to as people-centered co-creation. Accomplishing this is non-trivial, but detailed herein are considerations and processes that can be of aid in the effort.

\section{References}

Block, P. (1993). Stewardship: Choosing Service Over Self Interest, Berrett Koehler Publishers, Inc., San Francisco, CA.
Edgeman, R. L. (2000). "BEST Business Excellence: an Expanded View," Measuring Business Excellence, 4 (4), 15-17.

Edgeman, R. L. (2001). 'Business Excellence and Sustainable Development: BEST Integration,' Quality Australia, 16 (1), 27-30.

Edgeman, R. L. \& Eskildsen, J. (2012.) 'Viral Innovation: Integration via Sustainability and Enterprise Excellence,' Journal of Innovation \& Business Best Practice, 2012, Article ID 3614151, 13 pages, [Retrieved 30 April 2012]

http://www.ibimapublishing.com/journals/J IBBP/jibbp.html

Edgeman, R. L. \& Fraley, L. A. (2008). "A System of Profound Consciousness: Building Beyond Deming," Total Quality Management and Business Excellence, 19 (7/8), 683-707.

Edgeman, R. L. \& Hensler, D. A. (2001). "The AO Chronicle: Earth@omega or Sustainability@alpha?," The TQM Magazine, 13 (2), 83-90.

Edgeman, R. L. \& Hensler, D. A. (2005). "QFD and the BEST Paradigm: Deploying Sustainable Solutions," World Review of Science, Technology and Sustainable Development, 2 (1), 49-59.

Garvin, D. A. (1987). "Competing on the Eight Dimensions of Quality," Harvard Business Review, November-December, 101-109.

Hegel, GWF. (1807). 'The Phenomenology of the Mind,' Republished by Dover Publications (2003), Mineola, NY.

Hensler, D. A. \& Edgeman, R. L. (2002). "Modeling BEST Business Excellence: The Beginning," Measuring Business Excellence, 6 (2), 49-54.

Jaworski, J. \& Flowers, B. S. (1996). Synchronicity: The Inner Path of Leadership, Berrett-Koehler Publishers, Inc., San Francisco, CA. 
Jokisalo, E. (2008). "Innovation is for Everyone. Learning is for Everyone: an Interview with Anna Kirah," eLearning Papers, No. 8. ISSN: 1887-1542 [Online], [Retrieved October 20, 2009] www.elearningpapers.eu

Kano, N., Seraku, N., Takahashi, F. \& Tsuji, S. (1984). 'Attractive Quality and Must-be Quality,' Journal of the Japanese Society for Quality Control, April, 39-48.

Kelley, T. \& Littman, J. (2001). The Art of Innovation, Currency Doubleday, New York. NY.

Kirah, A. (2009). "Mindset and Methodologies: Creating Value through People-Centred Design and Concept Making," [Online], [Retrieved January 2, 2009], http://www.ucd.be/fileadmin/files/ucd_may _08/Anna_Kirah.pdf

Max-Neef, M. (1991). 'Human Scale Development,' Apex Press, New York, NY.

Patrick, F. (2002). "Evaporating Cloud and Other Thinking Processes," The TRIZ Journal. [Online], [Retrieved January 5, 2002], http://www.tocforme.com/ecandothertp.ht $\mathrm{ml}$

Porter, M. E. (1985). "Competitive Advantage: Creating and Sustaining Superior Performance," Free Press, New York, NY.

Porter, M. E. \& Kramer, M. R. (2006). "Strategy and Society: The Link between Competitive Advantage and Corporate Social Responsibility," Harvard Business Review, December, 78-93.

Price Waterhouse Change Integration Team Staff (1995). 'Better Change: Best Practices for Transforming Tour Organization,' Irwin Professional Publishing Group, Chicago, IL.

Reiss, S. (2000). "Who am I?: The 16 Basic Desires that Motivate Our Actions and Define Our Personalities, "Tarcher/Putnam Publishing, New York, NY.
Reiss, S. (2008). "The Normal Personality: A New Way of Thinking about People," Cambridge University Press, Cambridge, UK.

Senge, P. (1990). 'The Fifth Discipline: The Art \& Practice of the Learning Organization,' Currency Doubleday, New York, NY.

Terwiesch, C. \& Ulrich, K. T. (2009). Innovation Tournaments: Creating and Selecting Exceptional Opportunities, Harvard Business Press, Boston, MA.

Welton, D. (1999). 'The Essential Husserl: Basic Writings in Transcendental Phenomenology,' Welton, D. (ed), Indiana University Press, Bloomington, IN.

Williams, D. (2009). "The Human MacroOrganism as Fungus: an Interview with Marcos Viermenhouk," Wired. [Online], [Retrieved March 2, 2009], http://www.wired.com/wired/archive/4.04 /viermenhouk_pr.html 